\title{
WARGA NEGARA MUDA ERA MODERN PADA KONTEKS GLOBAL- NATIONAL: PERBANDINGAN DUA NEGARA JEPANG DAN INGGRIS
}

\author{
Muhammad Mona Adha \\ Universitas Lampung, Lampung, Indonesia \\ mohammad.monaadha@fkip.unila.ac.id
}

\begin{abstract}
Abstrak
Perkembangan dan peran serta warga negara muda di Jepang dan Inggris di dalam masyarakat telah mengalami perubahan secara signifikan dalam 30 tahun terakhir. Perkembangan yang lebih mengarah kepada perbaikan-perbaikan di berbagai bidang yang salah satunya adalah bagaimana meningkatkan peran serta para warga negara muda di kedua negara. Warga negara muda di Jepang dan Inggris melihat globalisasi dalam konteks perubahan sikap dan tanggung jawab individu secara signifikan untuk masa depan lebih baik. Kelompok warga negara muda merupakan potensi yang sangat penting untuk dikembangkan dan diarahkan, aspek pendidikan perlu menjadi perhatian khusus untuk membentuk warga negara muda menjadi warga muda yang berpotensi dan bermanfaat bagi negara. Disinilah pondasi yang sesungguhnya dibangun pada saat mereka berada dalam komunitas dan kehidupan masyarakat, karena disini kaum muda belajar secara spontan dan lebih natural. Warga negara muda muda harus mampu mengembangkan diri dan memiliki daya saing untuk mengikuti perkembangan globalisasi saat ini. Relasi-relasi sosial yang yang terbentuk dan menjadi bagian di aktivitas setiap individu telah mendorong warga muda di kedua negara yaitu Jepang dan Inggris memiliki rasa tanggung jawab sebagai warga negara.
\end{abstract}

Kata kunci : era modern, global-national, inggris, jepang, warga negara muda

\begin{abstract}
The development and participation of young citizen in Japan and the UK in the community has changed significantly in the past 30 years. Development more directed towards improvements in various fields, one of which is how to increase the participation of young citizens in both countries. Young citizen in Japan and the UK see globalization in the context of changing attitudes and individual responsibilities significantly for a better future. Young citizen groups are a very important potential to be developed and directed based on their skills, education aspect is one of important thing to develop potential young citizen as part of global-national. Environment is the real foundation when young citizen interact to the community, because young people learn spontaneously and more naturally. Young citizen must be able to develop themselves and gain competitiveness to keep up with the current developments in globalization. Social relations practiced and become part of the activities of each individual have encouraged young citizen in both countries Japan and the United Kingdom to take part in the country.
\end{abstract}

Keywords: Britain, global-national, Japan, modern era, young citizen 


\section{Pendahuluan}

Mengembangkan keterampilan bagi kaum muda di kedua negara ini telah menjadi perhatian pemerintah saat ini. Pemerintah sadar bahwa potensi besar yang dimiliki oleh kaum muda terlepas dari hal-hal yang ditimbulkannya, harus diarahkan dengan sangat baik. Life skills atau keterampilan hidup dalam pengertian ini mengacu pada berbagai ragam kemampuan yang diperlukan seseorang untuk menempuh kehidupan dengan sukses, bahagia dan secara bermartabat di masyarakat. Life skills merupakan kemampuan yang diperlukan sepanjang hayat, kepemilikan kemampuan berpikir yang kompleks, kemampuan komunikasi secara efektif, kemampuan membangun kerjasama, melaksanakan peranan sebagai warga negara yang bertanggung jawab, memiliki kesiapan serta kecakapan untuk bekerja, "However, in practice, the system channeled individuals into particular kinds of jobs determined by their schooling and with little chance of job mobility in their life." (Heater, 1999: 16), memiliki karakter dan etika untuk terjun ke dunia kerja.

Anak-anak muda diharapkan agar dapat mengembangkan dalam menggunakan rasio atau pikiran, dalam artian lebih aktif dalam menggali informasi, mengolah informasi dan mengambil keputusan secara cerdas sebagai warga negara. Dengan demikian bahwa kecakapan intelektual tidak terlepas dari proses berpikir masingmasing individu. Dimana dengan rasio atau pengetahuan yang dimilikinya, tiaptiap individu dapat menggali/mencari informasi sebanyak-banyaknya dan mampu mengambil keputusan untuk masa depan mereka.

\section{Kajian Literatur \\ Perbandingan Global-National Warga Negara Muda di Negara Jepang dan}

\section{Inggris}

Perkembangan masyarakat di Jepang dan Inggris khususnya warga negara muda di kedua negara ini telah mengalami perkembangan yang secara signifikan dalam 30 tahun terakhir. Dalam perkembangannya termasuk disini sebagai hasil interaksi kaum muda di kedua negara ini dalam generasinya sendiri dan antar generasi. Sehingga ada beberapa hal yang berhubungan dengan hal-hal yang positif dan hal-hal yang negatif yang menjadi perhatian negara untuk lebih memperhatikan kaum muda sebagai salah satu potensi yang harus dikembangkan. Selaku warga negara tentu akan terlibat pada penyatuan warga negara itu sendiri dan memiliki rasa kebersamaan identitas termasuk rasa kebangsaan (Connolly's, 2005). Dalam hal ini kita dapat melihat perbandingan sebagai kunci utama pengenalan sosial bagi kalangan pemuda di Jepang dan Inggris dan mengidentifikasi beberapa hambatan mendasar untuk mengembangkan kewarganegaraan.

Transformasi yang saat ini berkembang terkait dengan munculnya masyarakat modern dan terkadang mengganggu nilai-nilai kehidupan tradisional. Dikarenakan pada dasarnya individualistis dihasilkan oleh peran tiap-tiap individu itu sendiri dan mencakup keseluruhan sistem kepercayaan yang dianggap baik. Bagi para pemikir-pemikir sosial klasik, dalam perkembangannya secara mendasar paradoksal adalah adanya kebebasan individual dan kemajuan teknologi dan secara kronis dapat mengikis hubungan interaksi antar manusia. Meski begitu, modernitas juga dipengaruhi secara seimbang oleh perubahan sosial di mana cara-cara tersebut menghasilkan hal yang relatif stabil untuk membentuk hubungan sosial.

Artikel yang berjudul Becoming 
Citizens in Late Modernity: A GlobalNational Comparison of Young People in Japan and the UK (Gifford et al., 2014) memaparkan mengenai pluralisasi mendalam pada zaman modern seperti sekarang ini yang tentunya akan berpengaruh dalam menentukan pedoman atau nilai-nilai yang tercipta dalam kehidupan nyata. Menurut Connolly $(2005,2011)$ bahwa perbedaan antara politik warga negara dan yang akan menjadi warga negara, disini diusulkan bahwa kewarganegaraan bagi kaum muda harus dipandang sebagai dasar transisional ketika mereka menghadapi perbedaan dalam aspek kehiduupan kewarganegaraan, maka akan tampak orang-orang yang tidak lagi bekerja untuk waktu tertentu, melainkan menjadi warga negara yang seutuhnya.

$$
\text { Giddens (1991) menyatakan }
$$

bahwa karakter normatif dari sebuah tradisi dapat menghubungkan antara peristiwa yang telah lalu dengan yang sekarang, melalui kepatuhan apakah akan digabung normatif-normatif tersebut atau tidak. Hal ini memiliki pemahaman khusus ketika melihat group-group dalam rentang usia tertentu yang merupakan sebagai bagian dari konteks kehidupan tradisional yang kuat yang berulang-ulang dari generasi ke generasi selanjutnya, karena setiap generasi pada beberapa bagian kembali menemukan nilai-nilai tersebut dan kembali menghidupkan tradisi tersebut dalam kehidupan.

Membangun integrasi sosial masyarakat modern terlebih dahulu mampu menyadari konsep kewarganegaraan yang secara khusus fokus kepada penguatan dan kebijakankebijakan yang ada di dalam masyarakat seperti mengenai agama, etnik, bahasa, dan tradisi-tradisi yang mengarah kepada moral. Hal-hal yang semacam ini telah menjadi pondasi utama yang hadir secara berkelanjutan di setiap generasi dalam konteks sosialisasi. Saat ini wacana/konsep dari kewarganegaraan sudah mencapai puncak, Giddens menyatakan bahwa dengan kedewasaan masyarakat modern, interaksi antar individu, berubah dengan sangat cepat, begitu mendesak, dan lebih bersifat individualistis (Giddens, 1991). Giddens menyarankan bahwa pengalaman krisis pribadi dimana tiap-tiap pribadi dapat mengatasi pada prinsipnya, dapat mengupayakan dan memiliki kemampuan dalam relasi sosial dan keterhubungan konteks sosial sebagai bagian untuk memperjelas identitas diri masing-masing dengan keyakinan yang dimilliki oleh setiap individu. (Giddens, 1991). Bagaimanapun, dalam hubungan atau relasi sosial memiliki karakter yang dilingkupi oleh dilema moral, dan lebih kepada peristiwa-peristiwa yang saat ini terjadi, oleh karena itu maka semakin banyak kita menemukan pertentangan moral (Giddens, 1991).

Perubahan yang terjadi dalam kehidupan memberikan pengalaman sebagai keberadaan individu itu sendiri untuk menentukan pilihan dan keyakinan diri. Terlebih saat ini, dengan konflik yang terjadi akibat kondisi perubahan dalam setiap generasi memberikan dampak yang tidak baik terhadap kehidupan yang sudah maju seperti sekarang ini. (Edmunds \& Turner 2001) kemudian sebagai kaum muda yang berhadapan langsung dengan kondisi perubahan secara global dimana orang-orang dewasa dan berbagai institusi yang ada tidak dapat memberikan jawaban (Beck \& BeckGernsheim 2001). Konteks perubahan sosial global yang sangat cepat, suatu generasi dengan cepat terpisah dari pengalaman generasi masa yang telah lalu and hubungan antara sosial dan lembaga-lembaga politikal tidak menjadi lebih baik. Di waktu yang bersamaan paling tidak generasi masih 
memiliki sedikit kesadaran untuk saling mencari dan menyerap sejarah kecuali kesadaran tersebut tidak pernah dimunculkan (Edmunds \& Turner, 2001). Pengalaman yang dimiliki oleh generasi sebelumnya tidak begitu terbuka terhadap perubahan, karena masih mengalami isolasi yang cukup parah, dan memiliki jarak antar mereka sendiri, dan terpisah dari generasi yang lainnya, disinilah kemudian sebenarnya masih bisa melakukan perubahan perbaikan-perbaikan bagi generasi mereka sendiri dan disekitar mereka dan lebih memahami dengan peristiwa yang telah lewat.

Berdasarkan pendapat Honneth (1995, 2001), dilema moral pada era modern itu muncul dikarenakan adanya ketidakadilan yang terjadi dan bertentangan dengan apa yang dipahami dan menjelaskan upaya terhadap dilema moral ini terus menjadi perhatian. Relasi yang positif dibutuhkan untuk memenuhi kebutuhan pribadi inter subjektif yang dapat memberikan kontribusi kepada kemandirian moral individu dan integritas individu. Konsekuensi dari dilema moral adalah cedera moral dari hasil ketidakadilan, penghinaan, tidak hormat yang dapat menyamarkan keberadaan kehidupan interaksi manusia. Hubungan diri individu tergantung pada bagaimana mereka memandang kemampuan mereka dan hak-hak yang pada gilirannya ada konsekuensi dari bagaimana mereka memiliki atau tidak diakui oleh orang lain. Pengenalan/mengenal sangat penting bagi individu untuk mengembangkan rasa percaya diri, harga diri. Honneth kemudian berpendapat bahwa pengakuan memerlukan lembaga yang efektif seperti (keluarga, negara dan bekerja) dan sosial sesuai hubungan yang dapat memberikan pemahaman intersubjective antara individu yang memungkinkan diri untuk dikembangkan.

Artikel ini menjelaskan mengenai kewarganegaraan untuk mengoptimalkan kalangan muda di Jepang dan Inggris, sejauh ini ditandai oleh perubahan ekonomi dan perubahan sosial. Lockwood (1996) berpendapat bahwa hubungan kewarganegaraan dalam sistem politik diikuti oleh partisipasi individual dalam ruang lingkup politik dan birokrasi dimana hal ini sangat penting untuk sebuah organisasi dan melegitimasi persamaan status. Ini berarti aplikasi universal dan prinsip-prinsip abstrak kewarganegaraan dalam hubungan birokrasi memungkinkan seperti kesenjangan untuk menjadi efektif jika direproduksi serta dimodifikasi. Dari sudut pandang ini, individu dipandang suatu yang otonom, tapi status mereka dalam masyarakat tetap mesti tunduk pada pengelolaan dan pengawasan pasar dan negara dalam demokrasi kontemporer yang dinamis kapitalis untuk memastikan agar kewarganegaraan tetap ideal dimana terkadang aktualisasinya yang kurang lengkap (Lockwood 1996).

Kewarganegaraan harus mampu mengadaptasi negara modern untuk membentuk integrasi sosial dengan menghasilkan legitimasi stratifikasi warga negara, dalam merespon perubahan terhadap tuntutan politik yang dipengaruhi oleh struktur kelas dan status. Argumen di sini adalah bahwa ketika kita mempertimbangkan orangorang muda, stratifikasi warga negara menghasilkan pemahaman dan eksklusi yang semakin tidak kompatibel dengan integrasi sosial.

Saat memasuki masa dewasa berarti bahwa orang-orang muda didefinisikan sebagai poin yang mulai mengumpulkan hak formal kewarganegaraannya, karena sebelum 
mereka masuk masa dewasa, maka mereka mengalami pemahaman yang kurang dan harus didapatkan dari proses belajar untuk mendapatkan pengalaman bagi perkembangannya selaku anakanak muda.

Sebuah studi banding di Jepang dan Inggris mungkin menyiratkan sebuah metodologikal nasionalisme dalam konsep sosiologis ikut berpengaruh, proses global multidimensional yang telah diimplementasi dalam dunia sosial. Secara mendasar bahwa organisasi nasional adalah seperti sebuah prinsip dari penataan kemasyarakatan dan tindakan politik, dan tidak bisa lagi hanya sebagai titik utama orientasi bagi para pengamat sosial (Beck \& Sznaider 2010). Meski begitu, masyarakat nasional terdiri dari mendirikan dan solidaritas sosial yang diselenggarakan oleh negara dengan yurisdiksi teritorial, dimana kelompok-kelompok masyarakat tadi sebenarnya berbeda. Sebuah pendekatan global nasional kemudian memahami proses perubahan terkait dengan globalisasi dimediasi oleh secara nasional tertanam struktur dan lembaga yang signifikan untuk dilakukan, "Although they are partly enacted at the national scale, they are to a large extent novel and self evidently global formations." (Sassen, 2007).

\section{Hasil dan Pembahasan}

\section{Kaum Muda, Kelemahan dan Pemahaman Warga Negara di Jepang dan Inggris}

Di Inggris, untuk memperluas pemahaman mengenai ketimpangan sosial ekonomi, termasuk didalamnya perbedaan pendapatan bagi setiap usia kerja dalam tiga dekade terakhir, termasuk juga di dalamnya ras dan etnis (OECD 2011). Hal ini ditambah pula dengan peningkatan yang signifikan dalam hal buruh/pekerja (gaji yang rendah, pekerja paruh waktu), sementara mereka yang berkecukupan secara kehidupan mereka mendapatkan keuntungan dari gaji yang besar dan mesti taat pajak. Semenjak Inggris masuk ke dalam industrialisasi, hal ini menjadi akut dimana tergantung pada sektor jasa yang untuk penciptaan lapangan kerja. Transnasional bisnis secara khusus telah diatur langsung oleh deregulasi dan liberalisasi kerja undangundang. Dalam pengertian ini, masalah yang dihadapi oleh orang-orang muda di Inggris telah didefinisikan ulang dan terkait dengan proses globalisasi yang terkait dengan pemerintah yang mengejar sebuah globalisasi neoliberalisme dalam menanggapi penolakan post-imperial dan modernisasi masalah ekonomi nasional.

Kenaikan pengangguran usia muda di inggris, satu dari lima orang di Inggris pada usia 16 sampai 24 tahun dalam keadaan tidak bekerja (OECD, 2012), dapat mengakibatkan hilangnya satu generasi. Dalam tulisan ini, ada perhatian diantara para politisi dan para pengamat mengenai usia muda dan sikap yang anti sosial (Muncie, 2009) yang secara intensif dilihat dari para pemuda di kerusuhan di Inggris pada agustus 2011. Selanjutnya, penurunan tingkat partisipasi politik dan dirasakan kurangnya keterlibatan dari warga muda warga, sehingga hal ini menunjukkan keprihatinan tentang masa depan demokrasi dan pemuda/warga negara Inggris (Mycock \& Tonge 2012).

Di Jepang, sementara itu, telah berhasil memberlakukan suatu bentuk modernisasi barat yang dapat kita lihat menjadi salah satu dari negara yang paling maju dan ekonomi baru yang inovatif di dunia dengan kesejahteraan yang cukup dan standar hidup yang tinggi. Walaupun lebih beberapa tahun terakhir telah mengalami resesi yang berkepanjangan, Jepang dilihat sebagai 
sebuah negara yang masyarakat kapitalis relatif sukses yang menghindari banyak dari masalah sosial terkait di dalamnya dengan modernitas barat.

Wilkinson \& Pickett (2010) telah mengidentifikasikan Jepang sebagai negara yang mempunyai pola dasar yang dapat dibuktikan melalui argumen dengan konsep yang tinggi yang kemungkinan dapat mengurangi masalah-masalah sosial. Termasuk di dalamnya ada pernyataan bahwa Jepang lebih berhasil dalam integrai dan hubungan baik antar masyarakat, dibandingkan dengan Inggris bahwa masyarakat lebih kohesif di inggris yang dapat memberikan model terhadap masyarakat lainnya yang harus diutamakan. Masyarakat Jepang lebih menonjolkan komunitas/kelompok etnik nasional dengan lebih natural dan kompleks, memiliki etika yang tinggi, dan kebiasaan (Macfarlane, 2008). Kewarganegaraan di Jepang dinyatakan sebagai permulaan (kokuseki), dimana dapat diterjemahkan sebagai tugas atau negara (Wilis, 2006). Meskipun aspek dari modernisasi terus berjalan, integrasi sosial tingkat tinggi di Jepang berdasarkan oleh etnis. Sementara itu penting untuk tidak melebih-lebihkan konsep kekhasan jepang dan lebih banyak melihat itu sebagai jenis gemeinschaft mistis, tetap menjadi hal yang penting untuk menjadi sensitif terhadap suatu masyarakat nasional yang ada dengan berpedoma dengan kata kunci menghormati perbedaan kultural.

\section{Analisis Perbandingan Global- National di Kalangan Pemuda Di Jepang dan Inggris sebagai Warga Negara Modern}

Meski banyak penelitian secara nasional yang dilakukan dengan teknik dan penyajian data yang relevan, penelitian yang dilakukan harusl dianalisis melalui konseptual yang baru dan interpretif klasik yang mengakui national bisa menjadi salah satu langkah untuk menuju global (Sassen, 2010). Perbandingan ini berpusat kepada analisis kewarganegaraan. Pada satu sisi, masalah-masalah integrasi sosial di kalangan kaum muda di Inggris dan Jepang menjadi bahasan nasional dan secara khusus pada lokal, tetapi pada sisi yang lain ada indikasi-indikasi secara umum memberikan konsep lain mengenai gambaran hak yang lebih luas, yaitu kewajiban selaku warga negara dalam era globalisasi. Kemudian, kerangka pikir sangat penting untuk dikembangkan lebih luas lagi untuk menjadi warga negara yang berhubungan dengan rasa memiliki, kompetensi warga negara, dan kebajikan warga negara. Sama halnya dengan yang dikemukakan oleh Chan (2008: 532) dalam konteks global citizen bahwa "look the ways to "construct a new identity of the Japanese as global citizen", kemudian Chan juga mengutip David Held (2003) bahwa, "global citizenship is access to a variety of political engagement on a continuum from the local to the global."

Secara kritis tanggapan kebijakan terhadap masalah kewarganegaraan kaum muda yang dicoba untuk diatasi mengenai kekhawatiran adanya marginalisasi dan anggapan pasif kepada kaum muda Jepang. Namun, di kedua negara Jepang dan Inggris, ada sebuah konvergensi terhadap kebijakan yang tumpang tindih asumsi tentang identitas dan perilaku kaum muda dan kelemahan yang dirasakan dan dapat menuju kepada kegagalan. Padahal orang-orang muda baik di Jepang dan Inggris seharusnya tidak lagi dianggap sebagai warga negara yang pasif atau kekurangan, tapi juga dilihat sebagai individu yang menempati posisi yang unik terlibat dalam proyek sejarah pribadi dan otonomi politik yang menyiratkan bentuk-bentuk baru dalam 
situs kewarganegaraan.

Diferensiasi dalam generasi muda sebagai kelompok sosial (oleh ras, kelas, jenis kelamin, seksualitas, cacat serta) mau tidak mau menciptakan masalah dalam menempatkan anak muda sebagai sebuah kelompok homogen dan bagaimana kaum muda dapat berinteraksi dengan kelompok sosial lainnya. Dan peran serta pemerintah dalam merangkul dan mengarahkan warga negara ini untuk lebih mengembangkan potensi dirinya untuk masa depan diri mereka selaku kaum muda.

Melihat perbedaan-perbedaan tersebut, pendidik memiliki tanggung jawab untuk mengetahui karakteristik dari setiap siswa untuk dapat memunculkan kreatifitas dan memaksimalkan kemampuan yang mereka miliki sebagai kecakapan hidup. Sebanyak jumlah siswa dalam kelas, maka sebanyak itulah keanekaragaman yang dapat ditemukan oleh pendidik di dalam kelas. Untuk itu pendidik harus mampu memfasilitasi dan mengembangkan keberagaman potensi yang dimiliki oleh siswa agar tercipta proses pembelajaran yang lebih kondusif dan terarah serta bermakna bagi siswa.

Hal ini senada dengan yang dikemukakan oleh Tim Friedman (2013)

The context in which students develop civic knowledge and dispositions to be engaged as citizens has been impacted by several changes (Osler \& Starkey, 2006). In particular there have been increased levels of migration of peoples within and across continents and countries, often driven by economic and political imperatives to find work or escape ethnic, religious, and cultural tension. This has brought challenges concerning equality, equity, diversity, intercultural relations, and community cohesion. With regard to education, the cultural and language background of students has often been found to be associated with their educational performance.

Perbedaan yang ada merupakan informasi pelengkap antara yang satu dengan yang lain dalam berinteraksi. Mengapa dikatakan demikian? Karena setiap siswa berasal dari latar belakang yang berbeda, agama yang berbeda, dan mempunyai pengalaman hidup berbedabeda yang telah mereka dapatkan dalam kehidupan sehari-hari di keluarga, lingkungan sekolah, dan lingkungan masyarakat.

Kaum muda di Jepang kekuatannya bertambah lemah, terpinggirkan, dan tidak mendapatkan perhatian sama sekali, sebagai bukti bahwa mereka tidak dapat kesempatan untuk bekerja, dan masih bergantung dengan orang tuanya (Murakami, 2010). Jumlah pengangguran usia muda di Jepang meningkat secara tajam sejak awal tahun 1990an, satu dari sepuluh jumlah usia muda yang berumur 15 hingga 24 tahun adalah pengangguran (OECD, 2012). Meningkatnya jumlah kriminal yang dilakukan kaum muda dan sikap anti sosial merupakan suatu masalah sosial yang sangat serius dan hal ini mengindikasikan sebagai krisis moral nasional di Jepang (Nakanishi, 2003; Fenwick, 2007). Perubahan yang sangat tajam dan luar biasa ini dijadikan pengalaman untuk generasi selanjutnya di Jepang. Terlebih saat ini kaum muda Jepang sedang mengalami transisi oleh dunia barat, sehingga dapat disimpulkan bahwa terdapat konvergensi diantara kedua negara Jepang dan Inggris.

Budaya Jepang terkenal sangat erat sekali dalam kehidupan sehari-hari masyarakat Jepang. Budaya Jepang sangat terkenal di seluruh dunia, apakah 
itu dalam bentuk budaya bahasa, pakaian kimono, tradisi minum teh bersama, dan budaya-budaya yang lain dan diyakini keberadaannya oleh warga Jepang. Budaya Jepang sendiri sudah ada sejak ribuan tahun lalu. Senada dengan Jou (2014) berikut bahwa, "The Japanese culture is a multi-layered and complex system that has been developing within itself and forming new layers for thousands of years. Traditionally, the Japanese place great importance on the concept of wa, or group harmony. The value of the common greater good is more important than valuing ones's own needs. This principle is applied in schools, as well as social groups and, later in life, the workplace." Bentuk kehidupan kebudayaan Jepang, sepertinya masuk akal untuk melihat kedekatan sosial orang-orang Jepang, setidaknya sebagian telah ditopang oleh kombinasi dari bahan yang baik dan institusional egalitarianisme. Struktur kesempatan tradisi Jepang memungkinkan cukup mudah ditebak dan stabil transisi ke dewasa telah mulai terurai (Furlong 2008).

Kemudian berbicara tentang Inggris (UK), bahwa negara Inggris merupakan salah satu negara maju di dunia, baik di bidang pendidikan, pariwisata maupun ekonomi. Pembangunan di negara Inggris yang terus mengalami kemajuan memberi pengaruh terhadap budaya kerja. Pola hidup maupun pola pikir masyarakat Inggris dalam menghadapi tantangan zaman. Budaya di Inggris sudah berkembang ratusan tahun yang lalu sejak adanya revolusi Inggris yang cukup membuka mata hati masyarakat dunia kala itu. Revolusi Inggris memberi dampak besar terhadap pelbagai bidang kehidupan, termasuk sosial budaya dinegara ini terutama setelah perang dunia II.

Namun di sisi lain dalam hal perkembangan psikologis kaum muda di Inggris bahwa orang muda Inggris lebih mudah mendapatkan tekanan dibandingkan orang pada periode usia yang lain, sehingga banyak dari mereka yang melarikan diri kepada alkohol, rokok, dan obat-obatan terlarang. Hal ini diakibatkan adanya perkembangan kemajuan yang sangat pesat yang juga dipengaruhi oleh lingkungan. Oleh karena itulah pentingnya bagaimana kaum muda mulai belajar dalam lingkungan sosialnya. Senada yang dikemukakan oleh Davis (1948: 52) bahwa, "In turn the factual order exercise an influence on the normative system, for the norms must always refer to events in the real world and take into account factual situation." Berdasarkan konsep tersebut, warga negara muda harus belajar secara faktual atau secara nyata atas apa yang terjadi saat ini sehingga dapat memahami nilai-nilai atau norma yang patut dijalankan sehingga akan menjadikan diri mereka sebagai warga negara muda yang dapat berkontribusi bagi negaranya baik di Jepang dan Inggris.

Anak-anak muda di Inggris juga hendaknya ambil bagian dalam relasi sosial untuk lebih memperkuat jati dirinya, dan bergerak aktif sebagai warga negara. Senada dengan yang dikemukakan oleh (ICCS, 2010) bahwa, "to instil in young people a sense of national identity, a desire for social cohesion, and a willingness to get involved in their schools and communities as active citizens now and in the future."

Penjelasan di bawah memberikan gambaran bahwa tidak hanya hal-hal tadi di atas yang terjadi di kalangan muda Inggris. Tetapi permasalahan finansial juga berpengaruh bagi perkembangan warga muda Ingris. Di bawah 40 persen dari orang muda Inggris mengatakan bahwa kekhawatiran mengenai 
keuangan adalah masalah utama, tujuh dari 10 orang mengatakan, masalah finansial menyebabkan terjadinya setidaknya satu kali pertengkaran (argumentasi). Berikut adalah 10 hal yang membuat orang muda Inggris paling stres yang bersumber dari (www.tempo.co, 2014):

Kekhawatiran mengenai uang (38\%); (2) Pekerjaan (28\%); (3) Kurang tidur (24\%); (4) Masalah dengan pasangan (19\%); (5) Tidak punya cukup waktu (11\%); (6) Bentuk tubuh (10\%); (7) Berargumen dengan pasangan (8\%); (8) Masalah kesehatan (7\%); (9) Komitmen keluarga (5\%); (10) Berargumen dengan teman-teman $(4 \%)$.

Perhatian dan pemahaman di Jepang khususnya bagi kaum muda, yang biasanya di Jepang disebut dengan fenomena Hikikomori. Ahli Psikologi Saito (1998) menjelaskan bahwa Hikikomori adalah sebagai suatu kelompok orang-orang muda/kaum muda. Yamada (1999) menjelaskan bahwa pada akhir 1990an mempertimbangkan sejumlah "parasit single" yaitu orang-orang muda yang belum menikah yang masih tinggal dengan orang tua mereka. Para remaja usia muda ini digambarkan bahwa dengan tinggal bersama orang tua akan mereka akan merasa lebih privasi, dengan demikian otomatis pengalaman untuk menjadi orang tua menjadi lebih banyak dan berada pada posisi yang didukung oleh keuangan yang lebih dari cukup untuk dapat memfasilitasi anakanak mereka untuk barang-barang yang bermerk dan melakukan perjalanan. Untuk ukuran yang pasti dan komposisi pemahaman mengenai Hikikomori masih dalam perdebatan, karena disitu belum ada bukti pada bagian kaum muda Jepang memberikan kontribusi dalam hal kehidupan sosial dan ekonomi pada suatu waktu tertentu. Tapi sebenarnya Hikikomori sendiri dapat dibedakan menjadi sosial, psikologi, dan masalah kesehatan di Jepang, menjadi perhatian media. (Furlong, 2008) menunjukkan bahwa stigma yang melekat pada penolakan sosial budaya terjadi di jepang mungkin secara spesifik budaya, masyarakat barat menjadi lebih penting ditempatkan pada awal kesuksesan transisi ke dewasa dengan lebih sedikit kesempatan untuk kesempatan kedua dan jalur alternatif.

Meskipun di Inggris tidak ada perbandingan mengenai fenomena Hikikomori, hasil studi baru-baru ini menyarankan kepada anak-anak muda bahwa transisi menuju masa dewasa telah berubah secara signifikan dan harus mempersiapkan diri (Holdsworth \& Morgan, 2005). Bertambahnya jumlah orang-orang muda saat ini, melanjutkan kehidupan di rumah orang tua mereka hingga usia mereka untuk siap baik dalam umur memasuki 20 tahun lebih atau berumur 30an tahun, sehingga sering terjadi bahwa mereka belum siap untuk mandiri. Ini berarti bahwa meninggalkan rumah tidak lagi yang terkait dengan indikator lain dari dewasa seperti universitas, mendapatkan pekerjaan atau akan menikah. Hal ini memiliki dampak yang transformatif pada bagaimana definisi pemuda, dewasa dan kewarganegaraan yang dipahami oleh policy-makers dan masyarakat yang lebih umum. Namun, debat publik telah difokuskan pada dirasakan hilangnya kemerdekaan bagi anak-anak dan permasalahan dari orangorang muda untuk hubungan masyarakat mereka. Tingginya kasus penculikan anak dan pelecehan telah membantu melestarikan ide bahwa dunia di luar rumah adalah tempat bahaya untuk anak dan orang muda. Selanjutnya, media dan pemerintah terhadap sikap anti-sosial kampanye membangun anak muda sebagai ancaman bagi masyarakat harmoni. 
Sebuah laporan yang ditujukan kepada Youth Citizenship Commision, orang-orang muda mengungkapkan perasaan terhadap putusnya sebuah hubungan dari daerah mereka dan bahwa mereka sering dirasakan negatif dan dan ada sanksi dari kelompok mereka (Anderton \& Abbot, 2009). Pada saat keluar rumah, kaum muda memisahkan dirinya dari anggota komunitas likal dan menghindari ruang lingkup orang-orang dewasa. Hal yang senada dikemukakan oleh Harts (2009) bahwa penelitian yang telah dilakukan di pusat kota London telah ditemukan beberapa pengalaman mengenai diskriminasi yang berhubungan dengan umur/usia, kurang hormat dan kurang memiliki kesempatan dalam kehidupan mereka sehari-hari yang secara signifikan akan mencegah mereka untuk tergabung dalam kelompok-kelompok. Hal ini menunjukkan bahwa orang-orang muda di Inggris berbagi perasaan terbuang dari ruang publik dan pemutusan dari sumber-sumber lebih luas mengenai sosialitas mereka dengan Jepang sebagai mitra.

\section{Kesimpulan}

Globalisasi berarti bahwa kaum muda harus berinteraksi, masuk dalam kehidupan sosial, dan lembaga/institusi seperti keluarga, sekolah, komunitas, dan pekerjaan dimana akan bertambahnya permasalahan sosial dan ketidakpastian. Secara mendasar Kewarganegaraan dapat berkembang apabila setiap generasi memperhatikan akan hak dan kewajibannya yang dibangun pada kondisi yang stabil di generasi sebelumnya. Contoh-contoh perbandingan di Jepang dan gambaran mengenai Inggris sejauh mana menjadi warga negara juga berpotensi menjadi non-progressive, dan kaum muda hendaknya dapat mengantisipasi arus globalisasi itu sendiri dalam proses perkembangan diri warga negara muda. Di sisi lain dari penyatuan global suatu negara adalah adanya keutamaan kesamaan sejarah yang merupakan bagian dari identitas nasional yang dapat diinterpretasikan sebagai bentuk agama warga negara. Intervensi negara dalam membentuk identitas merupakan salah satu langkah yang penting untuk dilakukan sebagai penguatan, sebelum lebih jauh dipengaruhi oleh globalisasi. Dari sudut pandang ini, satu hal yang utama bahwa tanpa adanya bantuan atau respon dari pemerintah untuk membentuk identitas sosial ini dan ditambah dengan kebijakan-kebijakan yang tidak mendukung, maka konsep dari kewarganegaraan itu sendiri menjadi tidak jelas. Apa yang dapat kita temukan dari kedua negara seperti Jepang dan Inggris, sistem pendidikannya telah bertanggung jawab dalam memberikan nilai-nilai yang penting bagi pengembangan konsep kewarganegaraan dimana secara fundamental merupakan bagian yang menjadi fokus bangsa. Memberikan gambaran bahwa penting untuk benarbenar menjadi warga negara.

\section{Daftar Pustaka}

Anderton, A \& Abbott, R. (2009). Youth Engagement-Deliberative

Research. Report prepared for the Youth Citizenship Commission.

Beck, U \& Sznaider, N. (2010) Unpacking Cosmopolitanism for The Social Sciences: A Research Agenda. 2006. British Journal of Sociology, 61 (1), 381-403.

Chan, J. (2008). Another Japan is Possible: New Social Movements and Global Citizenship Education. Stanford: Stanford University Press.

Connolly, W.E. (2005). Pluralism. Durham, NC: Duke University Press. 
Connolly, W.E. (2011). A World of Becoming. Durham, NC: Duke University Press.

Davis, K. (1948). Human Society. New York: The Macmillan Company.

Edmunds, J \& Turner, B.S. (2002). Generations, Culture and Society. Buckingham: Open University.

Furlong, A. (2008). The Japanese Hikikomori Phenomenon: Acute Social Withdrawal Among Young People. The Sociological Review, 56 (2), 310-325.

Gifford, C., Mycock, A \& Murakami, J. (2014). Becoming Citizens in Late Modernity: A Global-National Comparison of Young People in Japan and the UK. Citizenship Studies, 18 (1), 81-98.

Giddens, A. (1991). Modernity and SelfIdentity: Self and Society in the Late Modern Age. Cambridge: Polity Press.

Hart, S. (2009). The 'Problem' with Youth: Young People, Citizenship and The Community. Citizenship Studies, 13 (6), 641-657.

Heater, D. (1999). What is Citizenship. UK: Polity Press.

ICCS. (2010). Young People's Civic Attitudes and Practices: England's Outcomes from the IEA International Civic and Citizenship Education Study (ICCS). UK: IEA International Civic and Citizenship Education Study (ICCS).

Jou. (2014). Basic of Japanese Culture (Japanese Culture).

http://iml.jou.ufl.edu/project s/Spring01/Newsome/culture.html . [Diakses 10 Oktober 2014]

Lockwood, D. (1996). Civic Integration and Class Formation. British Journal of Sociology, 47 (3), 531 550.

Murakami, J. (2010). Youth Identity Under the Fluidisation of Labour
From Mid 1990s Onward in Japan. Jimbungakkai-kiyou, 42, 116-128. Mycock, A \& Tonge, J. (2012). The party Politics of Youth Citizenship and Democratic Engagement. Parliamentary Affairs, 65 (1), 138-161.

OECD. (2011). Divided We Stand: Why Inequality Keeps Rising. Available from: http://www.oecd. org/els/social/inequality [Diakses 24 February 2011].

OECD. (2012). G20 Ministers must focus on young jobseekers, 15 May. Available from: http://www.oecd.org/document/39 $/ 0,3746$,en_21571361_44315115_ 50323559_1_1_1_1,00.html [Diakses $17 \overline{\text { May }}$ 2012].

Saito, T. (1998). Shakaiteki Hikikomori. Kyoto: PHP-shinsho.

Sassen, Saskia. 2007. A Sociology of Globalization. New York: W.W. Norton and Company.

Sassen, S. (2010). The Global Inside The National: A Research Agenda for Sociology. Sociopedia. http://www.columbia.edu/,sjs2/PD Fs/National.pdf [Diakses 20 February 2012].

Willis, D. B. (2006). Learning Culture, Learning Citizenship: Japanese Education and the Challenge of Multiculturalism. In: S. Lee, S. Murphy-Shigematsu and $\mathrm{H}$. Befu, eds. Japan's Diversity Dilemmas Ethnicity, Citizenship, and Education. Lincoln, NE: iUniverse, 47-74.

Wilkinson, R. G \& Pickett, K. (2010). The Spirit Level: Why Equality is Better for Everyone. Rev. ed. London: Penguin.

Yamada, M. (1999). Parasaito Singuruno Jidai [The age of the parasitic single]. Tokyo: Chikumashinsho. 